\title{
BAKTI KEPADA ORANG TUA SEBAGAI JALAN MENUJU KEDEWASAAN DIRI: REFLEKSI TEOLOGIS AMSAL 1:8-19
}

\author{
Thomas Onggo Sumaryanto
}

STFT Widya Sasana

Jalan Terusan Rajabasa No. 2, Malang, Jawa Timur

E-mail: titusajabrandsma@gmail.com

\begin{abstract}
ABSTRAK
Tulisan ini merupakan penafsiran terhadap Amsal 1:8-19. Persoalan yang ingin dijawab adalah bagaimana penjelasan teologis dan logis bahwa bakti kepada orang tua mengandung nilai yang menjadi jalan menuju kedewasaan diri menurut Amsal 1:8-19. Metode yang digunakan adalah analisis literer, dengan membagi Amsal 1:8-19 menjadi 2 bagian besar yaitu wejangan mendengarkan orang tua (8-9) dan peringatan untuk menjauhi orang berdosa (10-19). Temuan penelitian menunjukkan kemungkinan besar ajaran orang tua sengaja ditekankan pada bagian Amsal tersebut sebagai dasar untuk melawan bujukan atau tipuan orang berdosa dan hal itu merupakan bentuk bakti kepada orang tua. Refleksi teologis dari Amsal 1:8-19 secara umum menunjukkan bakti kepada orang tua membawa kaum muda pada kedewasaan diri, dan khususnya bagi orang Kristen, membentuk kaum muda menjadi orang yang dewasa di dalam Allah.
\end{abstract}

Kata Kunci: amsal, bakti, orang tua, kaum muda, nasehat

\begin{abstract}
This paper is an interpretation of Proverbs 1:8-19. The problem to be answered is how to explain theologically and logically that filial piety to parents contains values that become the path to self-maturity according to Proverbs 1:8-19. The method used is literary analysis, dividing Proverbs 1:8-19 into 2 major parts, namely advice to listen to parents (8-9) and warnings to stay away from sinners (10-19). The findings of the study indicate that it is most likely that the teachings of parents are deliberately emphasized in the Proverbs section as a basis for resisting the persuasion or deception of sinners and it is a form of devotion to parents. Theological reflection of Proverbs 1:8-19 generally shows that devotion to parents brings young people to maturity, and especially for Christians, shapes young people into mature people in God.
\end{abstract}

Keywords: proverbs, piety, parents, young people, advice 


\section{PENDAHULUAN}

Orang tua memiliki kewajiban untuk mendidik anak-anaknya. Anak-anaknya pun memiliki kewajiban untuk berbakti kepada orang tuanya. Dalam kehidupan seharihari, orang tua menjadi pendidik utama dan pertama. Banyak hal yang harus diajarkan kepada anak-anak, salah satunya kebijaksanaan hidup. Amsal 1:8-19 memberikan sebuah nasehat kepada anak-anak untuk selalu mendengarkan nasehat ayah dan ajaran ibu. Ajaran mereka itu indah bagaikan karangan bunga di kepala dan kalung di leher (Ams 1:9).

Wejangan di dalam kitab Amsal merupakan warisan yang patut dijaga. Beberapa ahli berpendapat bahwa kitab ini ditulis sesuai dengan kehendak Tuhan untuk membina kehidupan keluarga dan pemerintahan (Sin, 2020, hal. 3). Kitab Amsal digunakan sebagai modul pembelajaran di rumah atau istana. Dengan demikian, pendidikan untuk menuju kedewasaan diri sudah dimulai sejak dini. Setiap kaum muda dituntut untuk menjadi orang bijaksana dengan belajar banyak dari orang yang berpengalaman yaitu guru dan orang tua.

Penelitian ini berusaha menunjukkan nilai bakti kepada orang tua dalam Ams 1:8-19 sebagai jalan menuju kedewasaan diri. Permasalahan yang ingin dijawab adalah bagaimanakah wujud nilai bakti kepada orang yang dimaksud teks tersebut. Anak-anak atau kaum muda harus banyak belajar pada orang tua dan mau dengan setia meneladani mereka. Ada beberapa penelitian sebelumnya yang memiliki kesamaan dengan penelitian ini. Pertama, Yushak Soesilu meneliti penafsiran penggunaan rotan dalam Ams 23:13-14 tentang pendisplinan anak. Soesilu menjelaskan bahwa metafor penggunaan rotan mau menunjukkan usaha orang tua untuk mendidik anaknya bukan bertujuan menganiaya (Soesilo, 2016). Kedua, Alan Moss meneliti kebijaksanaan sebagai ajaran keluarga dalam Amsal 1-9. Dia menggunakan metode historis-kritis dan menjelaskan bahwa redaktur berusaha menunjukkan pentingnya pendidikan keluarga terutama bagi kaum Yudaisme diaspora (Moss, 1997). Kebaruan yang ingin ditunjukkan penelitian ini adalah penafsiran literer pada teks Ams 1:8-9 untuk menunjukkan pentingnya nilai bakti kepada orang tua. 


\section{METODE}

Metode penafsiran yang digunakan adalah analisis literer. Peneliti banyak menggunakan analisis semantik untuk membantu penafsiran. Analisis semantik merupakan sebuah usaha untuk mencari keterangan tentang kata, frasa atau kalimat yang digunakan pengarang sehingga membantu penafsiran pada teks (Pareira, 2018, hal. 210). Teks yang digunakan diambil dari Alkitab bahasa Indonesia terbitan Lembaga Biblika Indonesia. Pertama-tama, peneliti akan menunjukkan struktur dan pola Amsal 1:8-19. Struktur dan pola ini akan membantu analisis semantik pada kata atau frase yang perlu ditafsir. Kemudian penafsiran teks akan dilanjutkan dengan refleksi teologis dan logis.

\section{HASIL DAN PEMBAHASAN}

Secara umum, kitab Amsal dibagi menjadi 7 bagian. Pembagian ini banyak diterima oleh para ahli (Pareira, 2006). Bagian pertama adalah Ams 1-9. Bagian ini dianggap sebagai pendahuluan kitab Amsal. Para pembaca akan diantar untuk mencintai kebijaksanaan dan bagaimana cara untuk mendapatkannya. Jenis sastra yang dominan pada Ams 1-9 adalah wejangan atau nasehat. Ada beberapa ahli menunjukkan 12 wejangan dalam Ams 1-9. Namun yang terpenting Ams 1:8-19 merupakan wejangan pertama (Murphy, 1981, hal. 49).

Kitab Amsal ditulis untuk mendidik kaum muda menjadi orang bijaksana (bdk.1:1-6) (Pareira, 2001, hal. 70). Kebijaksanaan dibutuhkan dalam mengambil keputusan hidup. Kaum muda harus memiliki bahan pertimbangan yang cukup matang dalam mengambil keputusan hidup. Dalam Ams 1:4 dijelaskan bahwa amsal ini memberikan kecerdasan kepada orang yang tak berpengalaman. Jika diteliti lagi, Ams 1:4 menggunakan paralelisme sinonim. Orang yang tak berpengalaman disejajarkan dengan kaum muda. Hal ini bukan bermaksud untuk merendahkan kaum muda tetapi menegaskan bahwa kaum muda perlu banyak belajar untuk memperoleh pengalaman supaya tidak mengambil jalan kehidupan yang salah. Bertitik tolak dari Ams 1:4, para kaum muda diberikan nasehat dan peringatan pada Ams 1:8-19. 
Secara garis besar, Ams 1:8-9 dapat dibagi menjadi dua bagian yaitu nasehat mendengarkan ajaran orang tua (8-9) dan peringatan untuk menjauhi bujukan orang berdosa (10-19). Berikut struktur isinya:

\begin{tabular}{|c|l|}
\hline \multicolumn{1}{|c|}{ Bagian } & \multicolumn{1}{c|}{ Isi dan Ayat } \\
\hline I & nasehat mendengarkan ajaran orang tua (8-9) \\
\hline & a. $\begin{array}{l}\text { peringatan untuk menjauhi orang berdosa (10-19) } \\
\text { II }\end{array}$ \\
& b. $\begin{array}{l}\text { Peringatan untuk tidak mengikuti cara hidup orang } \\
\text { berdosa (15-18) }\end{array}$ \\
& c. kesimpulan: kesia-siaan cara hidup orang berdosa (19) \\
\hline
\end{tabular}

Selain itu, pola Ams 1:8-19 dapat ditemukan dari jenis sastranya. Jenis sastranya adalah wejangan dan biasanya wejangan memiliki dua bagian yaitu seruan dan motif/sebab. Pola ini ditemukan dalam ayat 8-18. Berikut pola paralel yang ditemukan:

\begin{tabular}{|c|c|}
\hline A & $\begin{array}{l}\text { Hai anakku, dengarkanlah didikan ayahmu....dan jangan } \\
\text { menyia-nyiakan ajaran ibumu... (ayat 8) }\end{array}$ \\
\hline B & $\begin{array}{r}\text { Sebab karangan bunga yang indah itu bagi kepalamu, dan } \\
\text { suatu kalung bagi lehermu....(ayat 9) }\end{array}$ \\
\hline A' & $\begin{array}{l}\text { Hai anakku, jikalau orang berdosa hendak....janganlah } \\
\text { engkau menurut;.... Hai anakku, janganlah engkau hidup }\end{array}$ \\
\hline B' & $\begin{array}{r}\text { Sebab percumalah jaring dibentangkan di depan mata } \\
\text { segala yang bersayap.... (ayat 16-18) }\end{array}$ \\
\hline
\end{tabular}

Pola ini menunjukkan paralelisme antitesis antara B dan B'. Antitesis menggunakan metapora untuk memperjelas adanya perbedaan tajam antara wejangan orang tua dan godaan orang berdosa. Dengan kata lain ayat 8-9 dapat dilihat sebagai dasar dari wejangan dalam Ams 1:8-19. Didikan ayah dan ajaran ibu menjadi dasar untuk menghadapi bujukan orang berdosa. 


\section{Bagian I: Nasehat Mendengarkan Ajaran Orang Tua (8-9)}

Pada bagian pertama, nasehat dibuka dengan frasa "hai anakku" (1:8). Frasa ini disebutkan sebanyak tiga kali $(1: 8,10,15)$. Sebutan anakku semakin menegaskan bahwa nasehat ini ditujukan kepada kaum muda. Jika secara menyeluruh, Amsal 1-9 secara konsisten menggunakan kata "anak" dalam arti orang muda sebagai orang yang menerima ajaran dari guru bijak (Clifford, 2017, hal. 161). Selain itu, nasehat ini memiliki kesejajaran dengan model tulisan kuno Mesir yaitu Egyptian Instruction of Amenemope (Dell, 2006, hal. 20). Amenemope memang dilihat hubungan kuat dengan kitab Amsal (Ruffle, 1977, hal. 29). Model ini memiliki kerangka nasehat seorang ayah kepada anaknya. Namun dalam konteks Amsal 1:8-19, model ini digunakan dalam sebuah metafora nasehat seorang guru kepada muridnya (Boadt, 2002, hal. 469). Seorang guru menasehati muridnya untuk mendengarkan nasehat orang tua.

Guru ini merupakan orang bijak. Dia sedang mengajar muridnya dengan kembali mengingatkan ajaran kebijaksanaan yang sudah didapatkan di dalam keluarga (Moss, 1997, hal. 429). Kel 20:12 dan U1 5:16 menegaskan bahwa manusia harus menghormati ayah dan ibu. Salah satu cara menghormati mereka adalah mendengarkan semua perkataan dan nasehat mereka. Pada waktu itu, jika ada seorang anak laki-laki tidak mendengarkan dan membangkang semua perkataan orang tua, dia bisa mendapatkan hukuman mati (U1 21:18-21). Sifat ini disebut sebagai sebuah kejahatan (U1 21:21). Menarik untuk diperhatikan pada bagian ini (ayat 8), kata ayah dan ibu disebutkan secara jelas untuk didengarkan didikan dan ajarannya. Penekanan yang sama bisa ditemukan pada Amsal 6:20. Kata perintah "dengarkanlah" menjadi sebuah ajakan untuk merefleksikan didikan ayah (Petrany, 2020, hal. 155). Ajaran ibu tidak boleh disia-siakan. Dengan kata lain ada keistimewaan dari didikan dan ajaran orang tua dan sang guru ingin para muridnya mendapatkan hal itu.

Mendengarkan wejangan orang tua digambarkan seperti karangan bunga indah di kepala dan kalung di leher (Ams 1:9). Metafora ini bermaksud menekankan bahwa dengan wejangan orang tua, seseorang bisa menjadi orang terhormat (Pareira, 2006, hal. 79). Karangan bunga di kepala dan kalung di leher merupakan tanda kehormatan. Jika diteliti, Ams 1:9 diulangi lagi pada Ams 4:9. Ams 4:1-9 memiliki kesamaan struktur yaitu dimulai dengan sebuah nasehat untuk mendengarkan orang tua (Ams 1:8 dan 4:1). 
Amsal 4:2 menjelaskan bahwa seorang ayah memberikan ilmu yang baik kepada anaknya. Semua petunjuk ayah akan memberikan kehidupan (Ams 4:4b) dan sang anak tidak boleh meninggalkannya begitu saja (Ams 4:6). Inilah keistimewaan yang akan didapatkan jika perintah dan nasehat orang tua dilaksanakan.

Didikan dan ajaran orang tua menjadi urgensi bagi kaum muda. Kaum muda harus menjadi orang yang penuh hikmat dan hormat. Dengan demikian, mereka mampu menghindari bujukan orang-orang jahat. Amsal 1:8-9 dilanjutkan dengan peringatan untuk menjauhi orang berdosa (1:10-19). Ada kemungkinan besar, ajaran orang tua mau ditekankan sebagai dasar untuk melawan bujukan atau tipuan orang-orang berdosa (Wendland, 2020, hal. 221). Satu-satunya pelindung adalah berpegang teguh pada apa yang telah dipelajari mengenai cara terbaik untuk bertindak (Boadt, 2002, hal. 469). Kaum muda sudah mempunyai bekal sejak dini untuk melawan tipu muslihat orangorang berdosa.

\section{Bagian II: Peringatan Untuk Menjauhi Orang Berdosa (10-19)}

Amsal 1:10 menunjukkan sang guru bijak mengingatkan kepada muridnya untuk tidak menuruti bujukan orang berdosa. Hal ini merupakan peringatan pertama dalam bagian II. Orang berdosa kerap dipandang selalu melakukan apa yang dianggap Tuhan sebagai kejahatan (bdk. Mzm 51:6). Dalam Ams 1:10, orang berdosa diidentikkan dengan bujukan untuk berbuat jahat. Dia selalu merencanakan perbuatan jahat kepada sesamanya. Amsal 1:11-14 memberikan sedikit gambaran bagaimana orang-orang berdosa merencanakan perampokan dan pembunuhan. Mereka mengambil apa yang bukan menjadi haknya. Orang-orang berdosa membuat sebuah kelompok dan menganggapnya sebagai kelompok pembawa keuntungan yang besar (Ams 1:11-13).

Amsal 1:11 diawali dengan kata "jika”. Hal ini menunjukkan hipotesis dari guru bijak. Meskipun demikian, ada kemungkinan besar hipotesis ini benar-benar nyata (Waltke, 2004, hal. 103). Sang guru bijak menunjukkan bagaimana kelompok orang berdosa mencari anggota baru. Mereka membujuk dengan menunjukkan keuntungankeuntungan besar tanpa harus bekerja keras siang dan malam (Ams 1:13-14).

Kesenangan untuk merampok dan membunuh orang lain dipamerkan sebagai kejagoan, keterampilan, dan kepandaiannya (Ams 1:11-12) (Pareira, 2006, hal. 79). Guru bijak hendak memberikan bekal pengetahuan kepada para murid. Jika suatu saat para murid mengalami hal yang sama, mereka dapat menghadapinya. 
Secara tidak langsung, nasehat ini mengajarkan orang menolak godaan dengan tegas (Pareira, 2006, hal. 80). Penolakan yang tegas berarti tidak memberikan ruang sama sekali pada godaan. Meskipun godaan datang berkali-kali, manusia tidak boleh terjebak begitu saja. Salah satu contoh ketegasan ini adalah kisah Yesus saat mengalami pencobaan di padang gurun (Mat 4:1-11 dan Luk 4:1-13). Yang perlu diingat iblis memiliki banyak cara untuk menggoda manusia. Yesus dengan tegas menolaknya dan akhirnya si iblis pergi meninggalkan Yesus.

Pada Amsal 1:15, guru bijak memberikan peringatan kedua. Dia meminta anakanaknya tidak meniru cara atau tingkah laku orang berdosa (15a). Peringatan ini hampir sama dengan ayat 10. Tingkah laku orang berdosa juga sudah dijelaskan pada ayat 1114. Ada kemungkinan sang guru melihat orang-orang muda memiliki rasa ingin tahu dan mencoba meniru mereka. Jika kedua sikap ini tidak diatur, para muridnya akan terjatuh pada cara hidup orang berdosa. Oleh sebab itu, sang guru menyatakan bahwa kaki para murid tidak boleh melangkah pada jalan orang berdosa (bdk. Ams 1:15b).

Pengunaan kata "kaki”" (Ams 1:15b dan 16) memiliki makna pengambilan keputusan arah hidup. Kaki orang muda tidak boleh sama dengan kaki orang berdosa. Orang berdosa sudah memutuskan sendiri untuk melakukan kejahatan dan memilih jalan kejahatan (Baris, 2015, hal. 138). Kaki orang berdosa menuju kejahatan dan bergegas-gegas untuk menumpahkan darah (Ams 1:16). Inilah yang menjadi alasan kuat untuk menolak mereka. Bahkan orang berdosa telah menjadi candu akan kejahatan (Waltke, 2004, hal. 105). Jadi sebuah metapora "menahan kaki daripada jalan mereka" bermakna jangan sekali-sekali mencoba untuk memulai kecanduan ini. Kaum muda diminta sekali lagi untuk tegas menolak godaan. Namun godaan ini berasal dari dalam diri sendiri. Rasa ingin tahu yang besar harus dibatasi.

Kemudian frase "bergegas-bergegas untuk menumpahkan darah" (Ams 1:16) memberikan sebuah pertanyaan. Apakah yang dimaksud dengan menumpahkan darah? Apakah ini sama dengan membunuh orang lain? Seorang ahli mengatakan bahwa frase ini memiliki pola yang sama dengan Yesaya 59:7 (Waltke, 2004, hal. 105).

\begin{tabular}{|c|cc|}
\hline $\begin{array}{c}\text { Mereka segera melakukan } \\
\text { kejahatan, }\end{array}$ & $\begin{array}{c}\text { Karena kaki mereka lari } \\
\text { menuju kejahatan }\end{array}$ \\
dan bersegera hendak & $\begin{array}{c}\text { dan bergegas-gegas untuk } \\
\text { menumpahkan darah orang yang } \\
\text { tidak bersalah (Yes 59:7) }\end{array}$ & menumpahkan darah. (Ams 1:16) \\
\hline
\end{tabular}


Ada kemungkinan bahwa penulis kitab Amsal sengaja menggunakan kata "darah" saja. Dia ingin menekankan bahwa orang berdosa memilih kejahatan dan membunuh diri sendiri. Jadi darah yang ditumpahkan adalah darah orang berdosa sendiri. Orang berdosa membawa diri sendiri kepada kematian dosa. Jadi guru bijak mau menunjukkan bahwa orang muda yang memilih melangkah bersama orang jahat, dia membunuh diri sendiri (Waltke, 2004, hal. 105). Penafsiran ini juga ditegaskan dalam Amsal 1:17-18.

Amsal 1:17 merupakan sebuah metapora. Beberapa ahli melihat bahwa metapora yang diberikan tidak jelas (Boadt, 2002, hal. 469; Pareira, 2006, hal. 78). Sang guru menggunakan metafora jaring yang dibentangkan untuk menangkap hewan bersayap. Tindakan ini disebut percuma bahkan sebuah kebodohan karena dilakukan di depan mata hewan tersebut. Ada yang berpendapat bahwa orang berdosa seperti burung yang naif. Burung ini telah mengetahui adanya jebakan tetap mengejar umpan tersebut (Boadt, 2002, hal. 469; Pareira, 2006, hal. 78). Waltke memberikan pendapat yang berbeda. Dia mendasarkan diri pada seni lukis Mesir kuno. Dalam lukisan tersebut digambarkan bagaimana orang berusaha menangkap burung dengan menebarkan jaring di belakang mata burung bukan di depan (Waltke, 2004, hal. 105). Alasannya adalah burung diberi naluri untuk menghindari apa yang terlihat di depan matanya. Pandangan ini sebenarnya sama-sama menunjukkan kebodohan orang berdosa. Peneliti lebih memilih untuk mengikuti pendapat Boadt dan Pareira.

Pendapat Boadt dan Pareira memiliki kesinambungan dengan Ams 1:18. Ayat 18 merupakan penjelasan metapora ayat 17 . Orang berdosa sedang menghadang darahnya sendiri dan mengintai nyawanya sendiri. Pernyataan ini juga merupakan antitesis dari ayat 11 . Orang berdosa memiliki niat untuk menjatuhkan orang lain tetapi sebenarnya dia menjatuhkan diri sendiri. Inilah kebodohan yang ingin ditunjukkan oleh guru bijak melalui metapora ayat 17. Meskipun mempunyai naluri untuk menghindari, orang jahat tetap mengikuti nafsu jahat.

Amsal 1:19 merupakan kesimpulan dari ayat 10-18. Setelah memberikan gambaran kehidupan orang berdosa, cara hidup ini adalah kesia-sian dan tidak pantas diteladani. Loba (kerakusan) akan keuntungan gelap selalu mewarnai hidup orang jahat. Yang dimaksud dengan keuntungan gelap adalah hasil yang didapatkan dengan 
merampas hak orang lain. Dengan kesimpulan ini, guru bijak menegaskan konsep dasar universal yaitu dosa membawa bahaya (Waltke, 2004, hal. 105).

\section{Refleksi Teologis}

Amsal 1:8-19 ditujukan kepada orang-orang muda. Wejangan ini diharapkan menjadi bekal kaum muda dalam perjalanan hidup menjadi orang dewasa. Kaum muda dianggap belum bisa mengambil keputusan secara matang. Oleh sebab itu, mereka harus mendengarkan pertimbangan dari orang yang lebih dewasa dan berpengalaman yaitu orang tua masing-masing. Orang tua adalah pendidik pertama dan utama. Kaum muda harus sungguh-sungguh menyadari ini.

Di tengah situasi pandemi, para ahli ilmu pendidikan sangat menekankan peran orang tua dalam pendidikan. Pembelajaran di sekolah dilakukan secara daring dan orang tua memiliki peran penting untuk membantu serta mengawasi anak-anaknya (Dini \& Suryadi, 2020, hal. 166). Di tengah kesibukan pekerjaan lain, orang tua tetap berjuang yang terbaik untuk pendidikan anaknya. Usaha keras ini tidak boleh dibiarkan berlalu begitu oleh anak-anak.

Amsal 1:9 telah menyatakan bahwa barangsiapa yang mendengarkan nasehat orang tua, dia akan menjadi orang terhormat. Dalam sepuluh perintah Allah (Kel 20:12 dan U1 5:16) sudah sangat jelas dikatakan bahwa menghormati orang tua merupakan sebuah kewajiban. Dalam terang Perjanjian Lama, bangsa Israel percaya bahwa Allah sendiri memberikan perintah ini. Allah memberikan perintah ini agar bangsa Israel mampu menjadi bangsa yang besar. Bangsa yang besar dimulai dari pendidikan di dalam keluarga (Packer, 2007, hal. 72). Keluarga merupakan dasar dari sistem sosial negara dan bangsa.

Dalam Injil Yesus Kristus juga menegaskan kepada orang-orang Farisi untuk kembali melihat esensi dari perintah Allah ini (Mat 15:1-20 dan Mrk 7:1-23). Mereka melanggar perintah untuk menghormati orang hanya demi adat istiadat nenek moyang (Mat 15:4 dan Mrk 7:10). Bahkan mereka merasa diri tidak perlu lagi menghormati orang tua karena sudah melakukan adat istiadat. Yesus pun menegur mereka bahwa bangsa ini memuliakan Allah dengan mulut tetapi hatinya jauh dari Allah (Mat 15:8).

Mendengarkan dan melaksanakan wejangan orang tua bukanlah hanya persoalan menghormati otoritas mereka kepada anak-anaknya (Eichrodt, 1957, hal. 38). Orang tua 
dianggap memiliki martabat ilahi dari Allah sendiri untuk mendampingi anak-anak menuju jalan kebenaran. Inilah panggilan hidup sebagai orang tua. Mereka memiliki kebijaksanaan normatif yang merupakan cerminan dari kasih Allah kepada semua umat manusia (Eichrodt, 1957, hal. 39). Dalam terang refleksi ini, Amsal 1:8-9 merupakan usaha guru bijak untuk menunjukkan cerminan tersebut di dalam diri setiap orang tua.

Pada bagian lain, Rasul Paulus juga memberikan nasehat kepada jemaat Efesus untuk menaati orang tua (Ef 6:1-4). Menghormati orang tua merupakan perintah penting bagi kehidupan sang anak. Bahkan Paulus menyatakan bahwa manusia harus menaati orang tua di dalam Tuhan (Ef 6:1). Ketaatan kepada Tuhan mendorong manusia untuk mendengarkan semua wejangan orang tua. Hingga akhirnya sang anak dapat mencapai kedewasaan diri dan menjadi pribadi yang bijaksana.

Anak-anak atau orang muda membutuhkan banyak ilmu dan pengalaman. Ketika sudah mencapai usia dewasa, kaum muda akan hidup mandiri dan tidak tinggal lagi bersama orang tuanya. Mereka dianggap telah mampu mengambil keputusan hidup untuk dirinya sendiri. Namun kadang-kadang kaum muda belum mempunyai pemikiran yang matang akan kehidupan ini. Amsal 1:8-19 menggambarkan bagaimana kemungkinan-kemungkinan yang akan dihadapi oleh kaum muda. Orang-orang jahat akan terus mencobai dan menggoda mereka. Segala usaha dilakukan agar orang-orang muda yang belum berpengalaman atau masih polos jatuh di dalam dosa. Orang-orang jahat menawarkan keinginan daging bukan keinginan Roh (bdk. Gal 5:16-26).

Rasul Paulus menyatakan bahwa salah satu buah dari keinginan Roh adalah penguasaan diri (Gal 5:22). Dalam kehidupan sehari-hari orang tua selalu mengajarkan kepada anaknya untuk menguasai diri sendiri. Penguasaan diri membantu manusia untuk menolak godaan dari dalam diri atau luar. Kedewasaan pribadi harus dicapai dengan banyak penguasaan diri. Sang guru bijak dalam Ams 1:10-19 memberikan sebuah teladan penguasaan diri. Meskipun orang berdosa menawarkan banyak kenyamanan tetapi semuanya itu sia-sia. Para murid diharapkan mampu dengan tegas menolak semuanya itu.

Sebagai orang Kristen, Amsal 1:8-19 dilihat sebagai wejangan yang menghantarkan kaum muda untuk hidup di dalam Roh Kudus. Salah satu caranya adalah berbakti kepada orang tua dengan mendengarkan dan melaksanakan ajaran dan didikan mereka. Wejangan ini akan mendewasakan kaum muda. Kaum muda dilatih 
untuk peka membedakan keinginan daging dan keinginan Roh. Menjadi pribadi yang dewasa secara rohani adalah sebuah keharusan pada zaman ini. Kaum muda Kristiani diharapkan juga mampu menjadi pribadi dewasa dalam Kristus.

Sang guru bijak sendiri dalam kitab Amsal memberikan bukti bahwa bakti kepada orang membuatnya menjadi orang berhikmat (bdk. Ams 4:1-27). Dia sendiri menyatakan kepada muridnya ketika sang guru masih kecil, ayah dan ibunya memberikan didikan dan ajaran (Ams 4:3-4). Didikan dan ajaran orang tua membuat sang guru mempunyai ilmu yang baik untuk kehidupan (Ams 4:2). Sang guru memberikan ilmu kepada muridnya karena sebelumnya, dia berbakti kepada orang tua. Oleh sebab itu dalam kitab Amsal 1-9, wejangan untuk mendengarkan dan melaksanakan ajaran orang tua banyak ditemukan.

Selain itu beberapa teolog menyatakan bahwa dalam PL dan PB berbakti kepada orang tua bukanlah berdasarkan kesepakatan antara orang tua dan anak. Menghormati orang merupakan hukum dari Tuhan yang wajib dilakukan oleh setiap kaum muda (Hermanto et al., 2021, hal. 83). Orang tua adalah rekan (partner) Allah dalam karya penciptaan manusia (Baker, 2011, hal. 259). Mereka menjadi pengantara untuk menghantar anak-anak hidup di dunia (bdk. Kej 1:26-28). Oleh sebab itu perintah Allah untuk menghormati orang tua (Kel 20:12 dan U1 5:16) membuat manusia menghormati karya Allah di dalam hidupnya. Menghormati orang tua berarti menghormati Allah sebagai sumber kehidupan.

Dalam PB, nilai berbakti kepada orang tua digunakan dalam perumpamaan tentang 2 orang anak (Mat 21:28-32). Yesus menceritakan perumpamaan ini untuk menegur para imam kepala dan tua-tua bangsa Yahudi yang merasa diri benar tetapi tidak melaksanakan kehendak Allah (bdk Mat 21:23-27). Di dalam perumpamaan, si anak bungsu digambarkan sebagai anak yang benar-benar berbakti kepada ayahnya. Pada awalnya perintah sang ayah ditolak, namun si bungsu menyesal dan melaksanakannya. Menurut peneliti, perumpamaan ini secara tersirat menunjukkan Yesus mau menunjukkan berbakti kepada ayah adalah melaksanakan perintahnya. Berbakti kepada Allah dianalogikan seperti seorang anak yang melaksanakan perintah ayahnya.

Rasul Paulus menasehati para jemaat Efesus untuk mencapai kedewasaan diri yang penuh (bdk. Ef 4:13). Bahkan dia menekankan perlunya menjadi manusia baru (Ef 
4:17-32). Manusia baru tidak mudah terpengaruh oleh pikiran orang yang sia-sia, penuh kebodohan, dan kedegilan (Ef 4:17-18). Paulus dengan tegas menyatakan orang-orang seperti itu adalah orang yang tidak mengenal Allah (Ef 4:17). Dalam Ams 1:8-19, sang guru menasehati muridnya untuk menjauhi orang-orang jahat karena jalan hidupnya adalah kegelapan dan kesia-siaan. Nasehat ini sejalan dengan nasehat Rasul Paulus. Dengan demikian, Kedewasaan diri dapat dicapai dengan rasa bakti kepada orang tua. Bakti kepada orang tua membuat sang anak menjadi orang terhormat (bdk. Ams 1:8-9) sebab orang tua akan membawa sang anak kepada kedewasaan diri di dalam Allah.

Didikan dan ajaran orang tua bertujuan untuk kedewasaan anak. Dalam Ulangan 6:1-9, Allah menyuruh kepada para orang tua untuk mengajarkan perintah Tuhan kepada anak-anak. Bahkan mereka harus mengajarkannya berulang-ulang supaya anakanak mengingat perjanjian Allah (bdk. U1 6:7) supaya mereka mencapai kedewasaan diri di dalam Allah. Inilah keistimewaan dari didikan dan ajaran orang tua dan sang guru bijak ingin para muridnya mendapatkan hal itu (bdk Ams 1:8-9). Orang tua memiliki tanggung jawab untuk mendidik demi pembentukan karakter anak (Metboki, 2020, hal. 57).

Untuk mendengarkan nasehat dan didikan orang tua, kaum muda harus mengutamakan sikap rendah hati. Rendah hati merupakan lawan dari keras kepala. Nasehat orang tua bisa menjadi percuma karena sifat keras kepala. Bahkan kehidupan kaum muda nantinya hanya dipenuhi dengan penyesalan tak berarti. Jika mengalami kesusahan, orang-orang tersebut mengingat semua wejangan tetapi semua sudah terlambat. Saat orang sudah jatuh di dalam godaan, dia sudah melukai diri sendiri (bdk. Ams 1:17). Orang tua selalu menginginkan yang terbaik bagi anak-anaknya. Motivasi ini harus selalu berada di dalam hati kaum muda.

\section{SIMPULAN}

Kaum muda dapat menjadi orang dewasa dengan nasehat orang tua. Ams 1:8-19 menunjukkan bahwa ajaran dan didikan orang tua membuat kaum muda menjadi orang terhormat. Mereka berusaha mengantar anak-anaknya kepada keinginan Roh bukan keinginan daging. Sang guru bijak berharap dengan mengingat dan melaksanakan nasehat orang tua, para muridnya bisa menolak dengan tegas keinginan daging yang ditawarkan oleh orang berdosa. Refleksi teologis Ams 1:8-19 menunjukkan bakti 
kepada orang tua membawa kaum muda pada kedewasaan diri. Secara khusus bagi orang Kristiani, bakti kepada orang tua membuat kaum muda menjadi orang yang dewasa di dalam Allah.

\section{DAFTAR PUSTAKA}

Baker, D. L. (2011). The Fifth Commandment In Context (J. K. Aitken, K. J. Dell, \& B. A. Mastin (Ed.); Hal. 253-268). De Gruyter.

Baris, M. (2015). Iniquities Ensnare The Wicked: The Ethical Theory Of Proverbs 1-9. Hebrew Studies, 56(May), 129-144. Https://Doi.Org/10.1353/Hbr.2015.0018

Boadt, L. E. (2002). Amsal. In D. Bergant \& R. J. Karris (Ed.), Tasfir Alkitab Perjanjian Lama (Hal. 463-491). Kanisius.

Clifford, R. J. (2017). Proverbs 1-9 As Instruction For A Young Man And For "Everyman." In S. C. Jones \& C. R. Yoder (Ed.), When The Morning Stars Sang: Essays In Honor Of Choon Leong Seow On The Occasion Of His Sixty-Fifth Birthday (Vol. 92, Nomor 1985, Hal. 129-142). Deutsche Nationalbibliothek. Https://Doi.Org/10.1515/9783110428148-010

Dell, K. J. (2006). The Book Of Proverbs In Social And Theological Context. Cambridge University Press. Https://Doi.Org/10.1017/CBO9780511488306

Dini, S. N. H., \& Suryadi. (2020). Pendidikan Masyarakat Di Masa Pandemi COVID19: Studi Kasus Peran Orang Tua Dalam Pendidikan Anak. Empower: Jurnal Pengembangan Masyarakat Islam, 5(2), 155. Https://Doi.Org/10.24235/Empower.V5i2.7359

Eichrodt, W. (1957). The Law And The Gospel: The Meaning Of The Ten Commandment In Israel Dan For Us. Interpretation: A Journal Of Bible And Theology, 11(1), 23-40. Https://Doi.Org/10.1111/J.1478-1913.1939.Tb00389.X

Hermanto, Y. P., Christine, C., Mukti, G. H., Santoso, C., \& Prayitno, Y. P. A. (2021). Sikap Hormat Anak Terhadap Orang Tua Berdasarkan Prinsip Alkitab. Evangelikal: Jurnal Teologi Injili Dan Pembinaan Warga Jemaat, 5(1), 80. Https://Doi.Org/10.46445/Ejti.V5i1.325

Metboki, R. J. A. (2020). Peranan Orangtua Kristen Dalam Membentuk Karakter Anak. Sesawi, 1(2), 55-63.

Moss, A. (1997). Wisdom As Parental Teaching In Proverbs 1-9. Heythrop Journal Quarterly Review Of Philosophy And Theology, 38(4), 426-439. Https://Doi.Org/10.1111/1468-2265.00058

Murphy, R. E. (1981). Wisdom Literature: Job, Proverbs, Ruth, Canticles, Ecclesiastes, And Esther. Wiiliam B. Eerdmans Publishing Company.

Packer, J. I. (2007). Keeping The 10 Commandments. Crossway Books.

Pareira, B. A. (2001). Kitab Suci Dan Pendidikan Nilai. Studia Philosophica Et Theologica, 1(2), 68-77. Https://Doi.Org/Https://Doi.Org/10.35312/Spet.V1i2.10

Pareira, B. A. (2006). Jalan Ke Hidup Yang Bijak: Amsal 1-9. Dioma.

Pareira, B. A. (2018). Studi Dan Riset Alkitabiah. In A. T. Raharso \& Yustinus (Ed.), Metodologi Riset Studi Filsafat Teologi (Hal. 195-239). Dioma.

Petrany, C. (2020). Fathers, Mothers, Sons, And Silence: Rhetorical Reconfiguration In Proverbs. Biblical Theology Bulletin, 50(3), 154-160. Https://Doi.Org/10.1177/0146107920934700 
Ruffle, J. (1977). The Teaching Of Amenemope And Its Will Connection With The Book Of Proverb. Tyndale Bulletin, 28, 29-68.

Https://Legacy.Tyndalehouse.Com/Tynbul/Library/Tynbull_1977_28_02_Ruffle Amenemopeandproverbs.Pdf

Sin, S. K. (2020). Pendekatan Topikal Dalam Menafsirkan Kitab Amsal. SOLA GRATIA: Jurnal Teologi Biblika Dan Praktika, 6(1). Https://Doi.Org/10.47596/Solagratia.V6i1.66

Soesilo, Y. (2016). Penggunaan Rotan Dalam Pendisiplinan Anak Menurut Kitab Amsal 23:13-14. DUNAMIS: Jurnal Penelitian Teologi Dan Pendidikan Kristiani, 1(1), 1. Https://Doi.Org/10.30648/Dun.V1i1.98

Waltke, B. K. (2004). The Book Of Proverbs Chapter 1-15: The New International Commentary On The Old Testament (R. K. Harrison \& R. L. Hubbrad Jr (Ed.)). Wm. B. Eerdmans Publishing Company.

Wendland, K. J. (2020). At Home With Wisdom : Structural Observations In Proverbs 7-9. Word And World, 40(3), 219-226. 